\title{
EXPLORING THE ANTECEDENTS OF BRAND EXTENSION SUCCESS: A RESEARCH ON AN ATHLETIC FOOTWEAR BRAND*
}

\author{
Çağatan Taşkın ${ }^{1 *}$, Gül Gökay Emel ${ }^{2}$ Onur Öztürk ${ }^{3}$ Gülcan Petriçli $^{4}$ \\ ${ }^{1}$ Assoc. Prof. Dr., Uludağ University, TURKEY, ctaskin@uludag.edu.tr \\ ${ }^{2}$ Asst. Prof. Dr., Uludağ University, TURKEY, ggokay@uludag.edu.tr \\ ${ }^{3}$ Res. Asst., Uludağ University, TURKEY, onurozturk13@gmail.com \\ ${ }^{4}$ Res. Asst., Uludağ University, TURKEY, gulcanp@uludag.edu.tr \\ ${ }^{*}$ Corresponding author
}

\begin{abstract}
Brand extension strategy which means using the current brand name when offering new products for the market, has become a frequently used branding strategy for firms since 1980s. Brand extension strategy is an appealing strategy for many firms since it helps reducing costs of creating a new brand and benefiting from the parent brand's brand equity. Thus, it is crucial for companies to understand the antecedents of brand extension success especially in athletic footwear segment that targets mostly young consumers.

The aim of this study is to explore the relationships among the antecedents of brand extension success from the generation $Y$ cohort's perspective on an athletic footwear brand and to propose marketing strategies. The proposed model aims to examine the relationships among success factors such as "parent brand's perceived quality", "perceived fit between parent brand and extension brand" and "perceived risk". For testing the proposed model in this study, a brand existing in the athletic footwear sector was determined. It is a very popular and favorable brand especially among the generation $\mathrm{Y}$ cohort. A hypothetical product was chosen for those consumers and collected data is analyzed by means of structural equation modelling. The sample is composed of university students in Bursa. This study is expected to make academic and practical contributions to the existing branding literature and the companies in athletic footwear industry, Turkey in particular.
\end{abstract}

Keywords: Brand Extension Success, Branding Strategies, Athletic Footwear Brand, Structural Equation Modelling, Bursa.

\section{INTRODUCTION}

Branding became a key issue since it has become quite easy to imitate the products of other firms. To gain competitive advantage against competitors in the market, branding became essential in the modern era of marketing. It is well known that the cost of introducing new products in markets is very expensive compared to past due to extreme increase in promotion activities such as advertising and the difficulty of creating active and effective distribution channels. As a result, more and more firms started using brand extension

* This study is financially supported by Scientific Research Projects Unit of Uludağ University, Project No: OUAP (İ) 2013/39. 
strategies, which means using an established brand name when offering a new product into markets.

The main advantage of brand extension strategy is the leverage effect of using the parent brand name. It helps reducing the promotion costs, faster access into markets and reducing the risks perceived by consumers. Brand extension is a very critical strategic decision for a firm because if the extension fails, wrong brand associations or cannibalism may occur and the most important asset of the firm, its brand equity, may be damaged because of a wrong choice of the extension. However, a successful brand extension strategy is expected to enhance the brand equity of the parent brand and reinforce its position in the market.

The aim of this study is to explore the relationships among the antecedents of brand extension success from the generation $Y$ cohort's perspective on an athletic footwear brand which is a very popular and favorable brand especially among the generation $Y$ cohort. A hypothetical product was chosen for those consumers and collected data is analyzed by means of structural equation modelling. This study is expected to make academic and practical contributions to the existing branding literature and the companies in athletic footwear industry, Turkey in particular.

\section{LITERATURE REVIEW}

Brand extension has got intense interest from both marketers and academicians and many studies has been conducted examining this topic. Aaker and Keller (1990) conducted two studies to obtain insights on how consumers form attitudes toward brand extensions. In one of their studies, reactions to 20 brand extension concepts involving six well known brand names were examined. In the second study, the effectiveness of different positioning strategies for extensions were examined. Boush and Loken (1991) explored the implications of considering a brand as representing a category consisting of its products. Keller and Aaker (1992) examined the factors affecting evaluations of proposed extensions from a parent brand that has or has not already been extended into other product categories. Specifically, the perceived quality of the parent brand and the number, success and similarity of intervening brand extensions, by influencing perceptions of company credibility and product fit were hypothesized to affect evaluations of proposed new extensions, as well as evaluations of the parent brand itself.

Boush (1993) examined how advertising slogans effected the evaluations of brand extensions. Different versions of a brand slogan were presented to each of three treatment groups before they evaluated six potential extensions of a hypothetical brand. Broniarczyk and Alba (1994) performed three experiments to explore the relative importance of brand associations. Dacin and Smith (1994) made two laboratory experiments and a survey, examining the effects of several brand portfolio characteristics on consumers' confidence in and favorability of their evaluations of subsequent brand extensions. Bottomley and Doyle (1996) examined the attitudes towards brand extensions by testing and generalizing Aaker and Keller's model. Bhat and Reddy (2001) investigated the impact of parent brand attribute associations and affect on brand extension evaluation by a model specifying the role of parent brand attribute beliefs and affect in consumer's initial evaluation of a brand extension using hypothetical extensions of different brands.

Czellar (2003) proposed a model of the antecedents and consequences of brand extension attitude based on the dominant cognitive paradigm. The model was consisted of four key processes, which were: The perception of fit, the formation of primary attitudes toward the extension, the link between extension attitude and marketplace behavior and the reciprocal effect of brand extension attitude on parent brand and the extension category attitude. Hem et al (2003) investigated the impact of category similarity, brand reputation, perceived risk and consumer innovativeness on the success of brand extension in fast moving consumer goods, durable goods and service sectors. The hypotheses were developed and tested on 701 consumers. Völckner and Sattler (2006) addressed the issue of the significance and relative importance of the determinants of extension success by investigating ten success factors. Their empirical analysis considered the direct relationships between success factors and extension success, the structural relationships among investigated factors and moderating effects. Buil et al (2009) examined the impact of perceived fit, brand type and country's culture on the consumers' attitude towards brand extensions and also on the parent brand equity by collecting data in three European countries: Spain, UK and Norway. A series of analyses of variance were conducted to test the hypotheses. Brown et al (2011) tried to determine the success drivers for B2B product-to-service brand extensions by developing a conceptual model.

Delvecchio and Smith (2005) examined the effects of perceived fit and extension product category risk. They argued that brand extension price premiums increase because of the ability of a well known brand to reduce the perceived risk that customers face in making their purchase decisions. Dens and Pelsmacker (2010) investigated how advertisements for brand extensions contribute to consumers' attitudes towards new line and brand extensions of highly familiar brands. They also investigated the relative importance of attitude 
toward the advertisement, parent brand quality and fit between the parent brand and the extension for brand extension evaluations with a sample of 754 people in Belgium. Doust and Esfahlan (2012) proposed an integrative model of the effect of brand extension on brand image. The four key processes of the model were; the formation of initial brand image toward parent brand, the perception of fit, the formation of attitude toward brand extension and the effect of brand extension attitude on parent brand image. Dwivedi and Merrilees (2013) investigated the impact of brand extensions on parent brand equity within the Asian context and they added brand trust as a new antecedent of brand extension feedback. They created a scenario of an Indian product brand hypothetically entering the service sector and a cross sectional survey of 327 Generation $Y$ respondents was conducted.

\section{ANTECEDENTS OF BRAND EXTENSION SUCCESS}

\subsection{Perceived Quality}

The major premise lies behind the use of brand extension strategy is that parent brands which consumers perceive to have a high quality provide greater leverage for extension products than the parent brands which have low quality (Völckner et al, 2010, p.382). Negative attributions for a proposed brand extension are less likely to appear when the parent brand is perceived to be of high quality (Keller and Aaker, 1992, p.39). Perceived quality can be defined as a global assessment of a consumer's judgment about the superiority or excellence of a product (Aaker and Keller, 1990, p.29). The perceived quality is expected to have a positive impact on the attitude toward the brand extension. If a parent brand is perceived as a quality brand, the brand extension should benefit from it, if parent brand is perceived as a low quality brand, the brand extension should be affected negatively (Aaker and Keller, 1990, p.29). Consumers generally tend to try brand extensions as long as the parent brand is perceived as a high quality brand (Abosag et al, 2012, p.1238).

If a parent brand offers a low quality extension, consumers are more likely to infer that all other products with the same brand name are also having a low quality, which threatens the profits from those other products of the parent brand. In addition, it can be said that parent brands would like to extend their brands with high quality products (Balachander and Ghose, 2003, p.5). High quality brands are usually priced higher than low quality brands. This would create more opportunities for high quality brands to charge higher prices for their extension products (Bao et al, 2010, p.341). Since brand extensions are new offerings for the markets, lack of information exists since consumers can not evaluate the perceived quality of the extensions at once. As a consequence, they perceive a risk in buying the brand extension. To reduce the risk, consumers usually rely on the parent brand's perceived quality. Perceived parent brand quality is an important information signal to infer perceived extension quality (Sichtmann and Diamantopoulos, 2013, p.569). Higher perceived quality of the parent brand leads to superior transfer benefits. Perceptions of consumers of the brand extension are generally expected to be positive if the parent brand has a high quality (Doust and Esfahlan, 2012, pp.42384239).

\subsection{Perceived Fit}

Reviewing the brand extension literature, the perceived fit has been found as a major factor which has a positive effect on brand extension evaluation. Many researchers have confirmed that there is a positive relationship between the perceived fit and brand extension evaluation. They also suggest that the firms should choose extension products similar to the parent brand or apply their promotion activities such as advertising to increase the perceived fit between the parent brand and the extension (Gierl and Huettl, 2011, p.120). Perceived fit is a key factor when it comes to evaluating brand extension process, bridging the gap between new product assessment and the beliefs of the parent brand (Salinas and Perez, 2009, p.52). Perceived fit affects the opinion on extended category directly. Consumers generally think that extension products which are non-related with the parent brand's category are not very trustworthy, which usually generates a negative thoughts about them. When categories of parent brand and the extension product are similar, consumers tend to evaluate the extension more positively (Salinas and Perez, 2009, p.53).

The perceived fit between the parent brand and the extension products is considered as a significant determinant of the success of brand extension. Even though there is a lack of an agreement on the definition of this concept, the idea behind the perceived fit refers to the degree of similarity between the parent brand and the extension that consumers perceive. This dimension reflects the degree of congruence between the parent brand and the new product offered by the firm. When firms offer a new product consistent with the parent brand, consumers perceive higher similarity between the other products of the parent brand and the extension product. Therefore, consumers tend to regard the extension products as more credible, which make them more willingness to buy the extension products. In addition to creating positive attitudes towards 
extensions, perceived fit may strengthen and also dilute the image of the parent brand. If there is a high similarity between the parent brand and the extension product, consumers usually have more favorable and positive evaluations of the parent brand, which helps avoiding the dilution. If there is a high similarity between the extension and the parent brand, consumers transfer their perceptions of quality and the other associations of the parent brand to the extension. This may lead to improving quality perceptions, brand image and the brand associations as well (Doust and Esfahlan, 2012, p.4240).

\subsection{Perceived Risk}

Perceived risk is seen as a multi dimensional construct, implying that consumers experience pre-purchase uncertainty regarding the type and degree of expected loss resulting from the purchase and the use of the product. Well known brands are often considered by consumers as a way of dealing with perceived risks. A parent brand which is extended into a new product category offers a new alternative to consumers and also has an impact on the risk perceptions of consumers. Well established parent brands generally play an important role as a risk reliever and increases the possibility of product trials. The risks perceived by consumers tend to decline and positive effects are likely to occur as people gain familiarity with the brand through the repeated experience (Hem et al, 2003, pp.788-789). Leveraging existing parent brand equity into new product categories may be useful for avoiding the risks associated with offering a new brand, by convincing consumers that the positive attributes related with the parent brand are also relevant to the new extension and benefiting from the positive attributes and associations of the parent brand (Barrett et al, 1999, p.3).

Consumers are more likely to transfer parent brand trust to products when consumers perceive the parent brand as safe and consider it as trustworthy. Therefore, they perceive that purchasing that parent brand's products as less risky (Wu and Yen, 2007, p.335). There are three types of risks when it comes to purchase decisions: Performance, financial and social risks. Each type of these risks are commonly viewed as being composed of two dimensions. The first dimension contains the outcomes associated with the decision of purchase. The second dimension of perceived risk is related with the certainty of outcomes. As potential outcomes are seen to be more negative or uncertain, the perceived risk related with the purchase decision increases. Well known brands provide a reliability that the outcomes of purchase will be consistent with the expectations and beliefs that customers associate with the parent brand. As a result, it can be said that consumers rely highly on well known parent brands to cope with risks (Delvecchio and Smith, 2005, pp.185186).

\section{RESEARCH METHODOLOGY}

\subsection{Conceptual Model and Research Hypotheses}

In this section, the conceptual model that examines the antecedents of brand extension success is presented. Perceived quality, perceived fit and perceived risk were selected as possible determinants of the brand extension success for the research. The conceptual model of the study is shown in Figure 1. In this conceptual model; "Perqual", "Perfit", "Perrisk" and "Extension" variables represent perceived quality, perceived fit, perceived risk and brand extension success respectively.

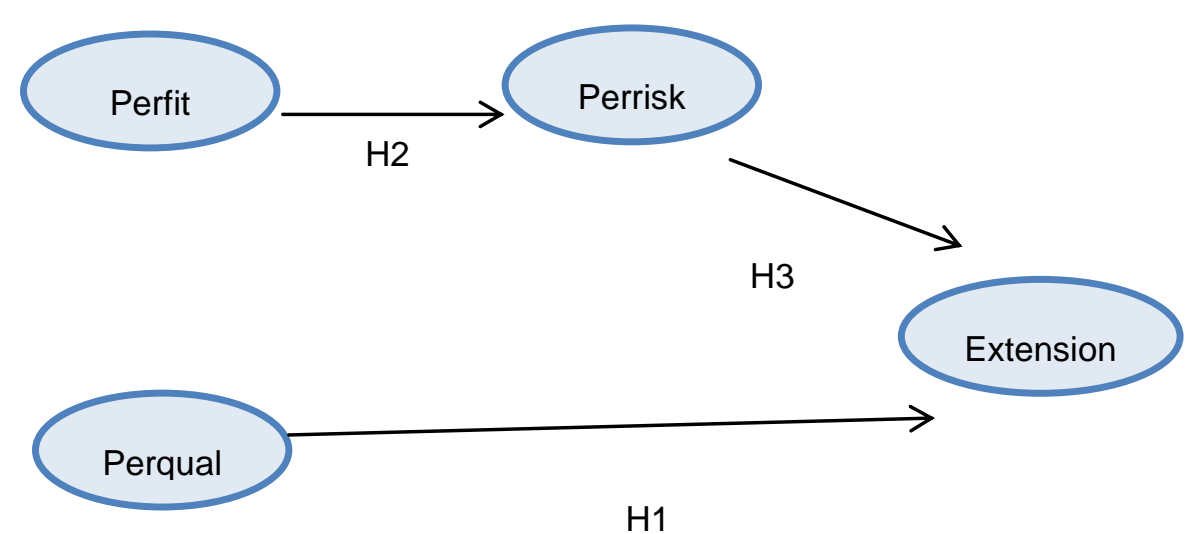

Figure1. Conceptual Model 
As seen from Figure 1, research hypotheses are:

$\mathrm{H} 1$ : Perceived quality has a positive effect on brand extension success.

H2: Perceived fit has a positive effect on perceived risk.

H3: Perceived risk has a positive effect on brand extension success.

After the implementation of the consumer survey, the reliability of the scale was measured by Cronbach's alpha. Next, an exploratory factor analysis has been executed. After providing the necessary conditions, a structural equation modeling analysis has been applied to test the conceptual model. The chosen athletic footwear brand is in a product category that is preferred by the generation $\mathrm{Y}$ cohort mostly. The sample of this research was chosen as the university students in Bursa.

\subsection{Findings}

\subsubsection{Reliability Analysis}

A scale used in social sciences is generally tested by Cronbach's Alpha. The data gathered in the research has been transferred into the IBM SPSS 22 program. Cronbach's Alpha values are; 0,84, 0,93, 0,80 and 0,92 for perceived quality, perceived fit, perceived risk and brand extension success factors.

\subsubsection{Testing the Basic Structural Model}

In this section, the results of the structural model are given. The structural model and the standardized path coefficients are shown in Figure 2.

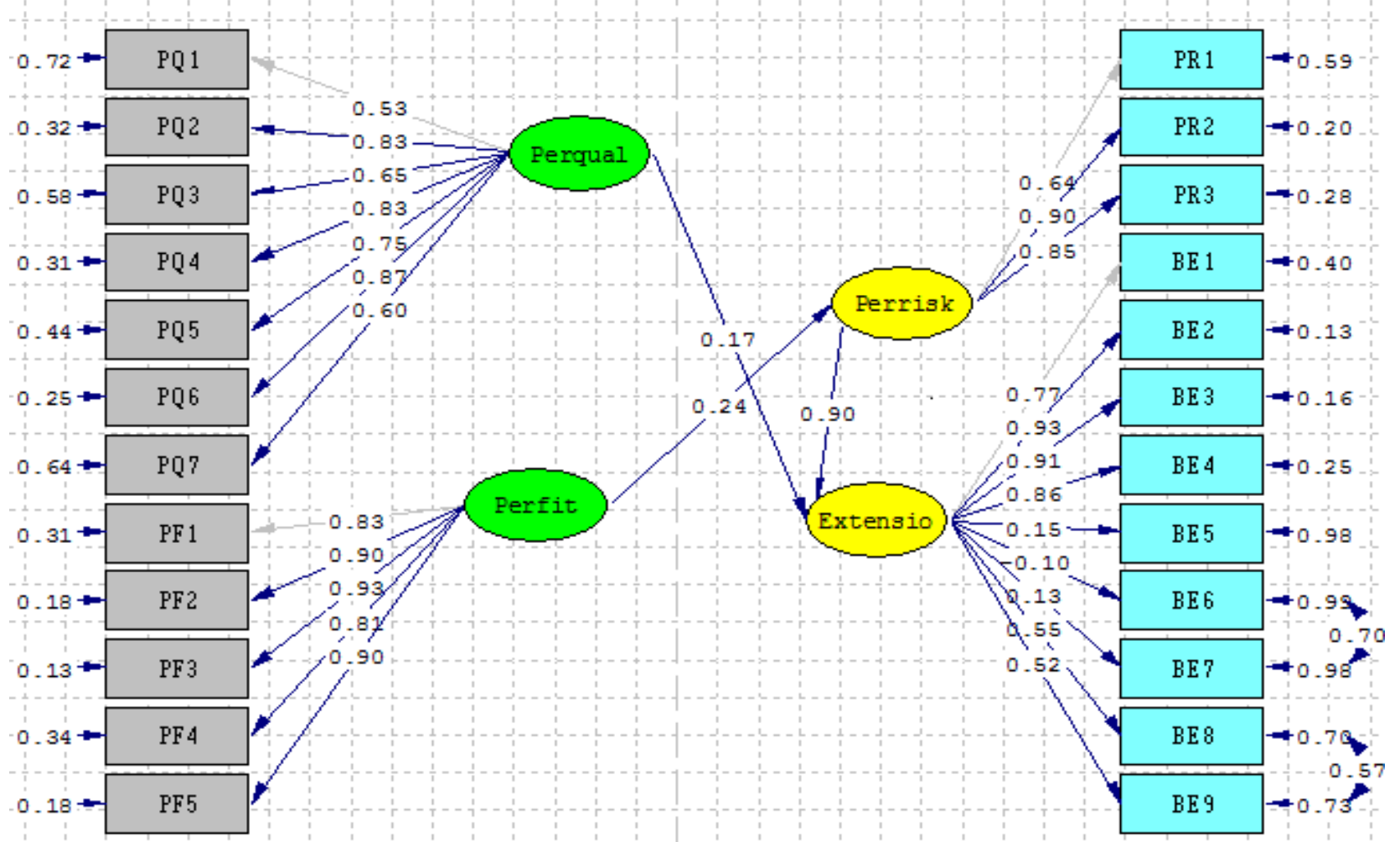

Figure 2. Structural Model and Standardized Path Coefficients

All the paths were found to be statistically significant. Results of the hypotheses are given in Table 1 .

Table 1: Hypotheses Results

\begin{tabular}{|l|l|}
\hline Hypotheses & Accepted/Rejected \\
\hline H1 & Accepted \\
\hline H2 & Accepted \\
\hline H3 & Accepted \\
\hline
\end{tabular}


The paths of the model and the path coefficients are given in the Table 2.

Table 2: Paths and Coefficients

\begin{tabular}{|l|l|}
\hline Paths & Value \\
\hline Perqual- Extension & 0,17 \\
\hline Perfit- Perrisk & 0,24 \\
\hline Perrisk- Success & 0,90 \\
\hline
\end{tabular}

As seen in Figure 2, perceived quality has a direct and positive effect on brand extension success. Perceived fit has a positive and direct effect on perceived risk and perceived risk has a positive and direct effect on the brand extension success. The path coefficient between perceived quality and the brand extension success is 0,17 . The path coefficients between perceived fit and perceived risk and the perceived risk and the brand extension success are 0,24 and 0,90 respectively. It shows that the perceived fit has an effect on the brand extension success with the mediating affect of perceived risk and the perceived risk has a positive and direct effect on brand extension success.

The reliability of the structural model can be measured by various statistics. These are called goodness of fit statistics generally. Common used fit statistics are shown in Table 5. Goodness of fit statistics indicate that the structural model is valid.

Table 3: Goodness of Fit Statistics

\begin{tabular}{|l|l|}
\hline The Goodness of Fit Statistics & Value \\
\hline Chi Square/Degrees of Freedom & 4,67 \\
\hline RMSEA & 0,10 \\
\hline NFI & 0,88 \\
\hline CFI & 0,89 \\
\hline RMR & 0,09 \\
\hline Standardized RMR & 0,10 \\
\hline GFI & 0,87 \\
\hline AGFI & 0,84 \\
\hline
\end{tabular}

When controlling the goodness of fit statistics; the GFI, AGFI, CFI and NFI values are some important values for checking the model. It can be seen in the statistics that these values are $0,87,0.84,0,89$ and 0,88 respectively. These values show that the structural model has good values. The RMSEA, RMR and SRMR values are also good for the model.

\section{DISCUSSION AND IMPLICATIONS}

Perceived quality is a very familiar and one of the most investigated determinants in the brand extension literature. In Aaker and Keller's (1990) pioneer work of brand extension, they have found that perceived quality of the parent brand was strong only if there was a basis of similarity between the two product classes. Keller and Aaker (1992) came to a conclusion in their study of brand extension, that perceived quality is an important determinant in brand extension success. They found that parent brands with high quality stretch farther than average quality brands. They also emphasized that high quality brands lead to more favorable extension evaluations than the brands with average quality.

Völckner et al (2010) investigated the role of parent brand quality for service brand extension success using partial least squares modeling and they found that parent brand quality is the dominant success driver for service brand extensions. Bao et al (2010) explained that when the perceived quality of the parent brand is low, consumers tend to have lower expectations for the extensions. Parent brand with lower quality may result in weak evaluations of extensions. Sichtmann and Diamantopoulos (2013) found that perceived quality of the parent brand has a mediating role between the brand origin image and the success of brand extension evaluations. 
Similar to previous findings, perceived quality was found to have an effect on brand extension success directly in this study. It is not surprising that consumers look for quality products when they consider about shopping. Quality has become a necessity, not a privilege in the modern era of marketing compared with old fashioned marketing. Considering the generation $Y$ cohort, it can be said that buying and consuming high quality products, these young consumers feel themselves much comfortable as quality products often create a show off effect for other consumers.

Perceived fit is seen as a very important determinant of brand extension success in the brand extension literature. Gierl and Huettl (2012) tested three models to gain insights of understanding the effect of perceived fit on brand extension success. Their findings show that brand attitude transfer model best describes the role of perceived fit. They indicate parent brands can increase their success of extension products by increasing the perceived fit between the core product and the extension product. Salinas and Perez (2009) found that perceived fit between the new product and either the remaining products or the brand image are able to strengthen consumer attitude. In addition, if the extension has a low fit, there will be a negative effect on the attitude toward the brand, regardless of the attitude toward the extension. It is also important to understand that the perceived fit may affect the attitudes not only toward the extension, but also toward the parent brand as well.

Völckner and Sattler (2006) investigated the effect of possible ten success factors on brand extension success. Their findings show that the perceived fit between the parent brand and the extension is the most important driver of brand extension success. In their study of examining the role of the perceived fit between a parent B2B brand and its extension product by applying Aaker and Keller's consumer evaluation model with the residual-centering technique to empirically assess the fit extension, Tang et al. (2008) found that the consistency of brand concepts between the parent B2B brand and the B2C extension product is the dominant factor influencing consumer evaluations.

According to brand extension literature, consumers' evaluations of brand extensions may be influenced by their perceptions of the risk associated with new products or new categories. Hem et al (2003) found that perceived risk is not as important in fast moving consumer goods as in other industries. When they investigated the service sector, however, they found that the characteristics of services make it difficult for consumers to evaluate the extensions; the impact of perceived risk may encourage consumers to prefer brand extensions from well known parent brands since they help reducing the negative consequences from making a wrong decision.

Delvecchio and Smith (2005) examined the effects of the perceived fit and extension product category risk in their study. Their results show that fit with the extension category, social risk and financial risk affect brand extension price premiums. As the degree to which brands with high extension category fit are rewarded in terms of a price premium would be increased as each type of category risk increases. However, a positive fitprice premium relationship holds only in product categories meeting a certain risk profile. Price premiums differ as a function of fit only when the extension category is one with high financial and social risk.

In this study, perceived fit is found to have an effect on brand extension success through the perceived risk. In most studies, perceived fit was found as a direct variable on brand extension success. Perceived fit is an important variable when it comes to brand extension because consumers generally like to buy extension products because it eases their purchase decision and helps consumers to transfer their associations into the extension product easier and thus, it helps consumers to reduce the risk levels they perceive. Appropriate selection of the parent brand and the extension product and its product category can affect the fit consumers perceive. Consumers usually make their purchase decisions to lower the risks because of their nature. So the results derived in this study can be interpreted as rational.

\section{LIMITATIONS AND FURTHER RESEARCH}

This study has a geographical limitation. The research was conducted only in Bursa. The data are based solely on responses from the people who live in one city of Turkey. Therefore, conducting a study in a larger geographical area can contribute to the literature. Another limitation of the study is that only one brand was examined.

This research could add depth to brand extension literature. There are only few studies that have investigated brand extension success through the point of view of generation $Y$ cohort. The literature may be improved by conducting a study in a larger geographical area. Brand extension strategy has taken a lot of interest among the academicians and the managers of the companies in the private sector. This study examines the apparel industry and it may be expanded into other industries as well. 


\section{REFERENCE LIST}

Aaker, A. D. and Keller, L. K. (1990). Consumer Evaluations of Brand Extensions. Journal of Marketing, vol.54 (1).

Abosag, I., Roper, S. and Hind, D. (2012). Examining the Relationship Between Brand Emotion and Brand Extension Among Supporters of Professional Football Clubs. European Journal of Marketing, vol.46 (9).

Balachander, S. and Ghose, S. (2003). Reciprocal Spillover Effects: A Strategic Benefit of Brand Extensions. Journal of Marketing, vol.67 (1).

Bao, Y., Sheng, S. and Nkwocha, I. (2010). Product Difficulty Incongruity and Consumer Evaluations of Brand Extensions. Journal of Retailing and Consumer Services, vol.17.

Barrett, J., Lye, A. and Venkateswarlu, P. (1999). Consumer Perceptions of Brand Extensions: Generalising Aaker\& Keller's Model. Journal of Empirical Generalisations in Marketing Science, vol.4.

Bhat, S. and Reddy, K. S. (2001). The Impact of Parent Brand Attribute Associations and Affect on Brand Extension Evaluation. Journal of Business Research, vol.53.

Bottomley, A. P. and Doyle, R. J. (1996). The Formation of Attitudes Towards Brand Extensions: Testing and Generalising Aaker and Keller's Model. International Journal of Research in Marketing, vol.13.

Boush, M. D. and Loken, B. (1991). A Process-Tracing Study of Brand Extension Evaluation. Journal of Marketing Research, vol.28 (1).

Boush, M. D. (1993). How Advertising Slogans Can Prime Evaluations of Brand Extensions. Psychology\&Marketing, vol.10 (1).

Broniarczyk, M. S. and Alba, W. J. (1994). The Importance of Brand in Brand Extension. Journal of Marketing Research, vol.31 (2).

Brown, B., Sichtmann, C. and Musante, M. (2011). A Model of Product-to-Service Brand Extension Success Factors in B2B Buying Contexts. Journal of Business\&Industrial Marketing, vol.26 (3).

Buil, I., De Chernatony, L. and Hem, E. L. (2009). Brand Extension Strategies: Perceived Fit, Brand Type, and Culture Influences. European Journal of Marketing, vol.43 (11).

Czellar, S. (2003). Consumer Attitude Toward Brand Extensions: An Integrative Model and Research Propositions. International Journal of Research in Marketing, vol.20.

Dacin, A. P. and Smith, C. D. (1994). The Effect of Brand Portfolio Characteristics on Consumer Evaluations of Brand Extensions. Journal of Marketing Research, vol.31 (2).

Delvecchio, D. and Smith, C. D. (2005). Brand-Extension Price Premiums: The Effects of Perceived Fit and Extension Product Category Risk. Journal of the Academy of Marketing Science, vol.33 (2).

Dens, N. and De Pelsmacker, P. (2010). Advertising For Extensions: Moderating Effects of Extension Type, Advertising Strategy, and Product Category Involvement on Extension Evaluation. Market Lett, vol.21.

Doust, V. H. and Esfahlan, N. H. (2012). The Effect of Brand Extension Strategies on Brand Image: An Integrative Model and Research Propositions. African Journal of Business Management, vol.6 (11).

Dwivedi, A. and Merrilees, B. (2013). Brand-Extension Feedback Effects: An Asian Branding Perspective. Asia Pacific Journal of Marketing and Logistics, vol.25 (2).

Gierl, H. and Huettl, V. (2011). A Closer Look at Similarity: The Effects of Perceived Similarity and Conjunctive Cues on Brand Extension Evaluation. International Journal of Research in Marketing, vol.28.

Hem, E. L., De Chernatony, L. and Iversen, M. N. (2003). Factors Influencing Successful Brand Extensions. Journal of Marketing Management, vol.19.

Keller, L. K. and Aaker, A. D. (1992). The Effects of Sequential Introduction of Brand Extensions. Journal of Marketing Research, vol.29 (1).

Salinas, M. E. and Perez, M. J. (2009). Modeling the Brand Extensions' Influence on Brand Image. Journal of Business Research, vol.62. 
Sichtmann, C. and Diamantopoulos, A. (2013). The Impact of Perceived Brand Globalness, Brand Origin Image, and Brand Origin-Extension Fit on Brand Extension Success. Journal of the Academy of Marketing Science, vol.41.

Völckner, F. and Sattler, H. (2006). Drivers of Brand Extension Success. Journal of Marketing, vol.70 (2).

Völckner, F., Sattler, H., Hennig-Thurau, T. and Ringle, M. C. (2010). The Role of Parent Brand Quality for Service Brand Extension Success. Journal of Service Research, vol.13 (4).

Wu, C. and Yen, C. Y. (2007). How the Strength of Parent Brand Associations Influence the Interaction Effects of Brand Breadth and Product Similarity With Brand Extension Evaluations. Journal of Product\& Brand Management, vol.16 (5). 